\title{
El status quo y las contramedidas sobre las reliquias de piedra del Templo Putuo Zongcheng en Chengde
}

\author{
The status quo and the countermeasures about the stone relics of \\ the Putuo Zongcheng Temple in Chengde
}

\section{承德普陀宗乘之庙石质文物现状问题及对策}

\section{Haijia Wu / 吴海嘉}

Instituto Arqueológico de Reliquias

en Chengdu/ Chengdu Relics Archeological

Institute /成都文物考古研究院

Sichuan, China.

ruihai58485@163.com
Recibido 11/12/2019 Revisado 02/01/2020

Aceptado 02/01/2020 Publicado 31/01/2020

\section{Resumen:}

El Templo Putuo Zongcheng es el templo más grande en los ocho templos exteriores de "Residencia de Montaña de Chengde y Ocho Templos Exteriores". Conserva una gran cantidad de reliquias culturales de piedra y tiene un alto valor histórico, artístico y científico. Bajo la influencia del medio ambiente natural a largo plazo y las actividades de producción humana, estas reliquias culturales de piedra han experimentado enfermedades climáticas en diversos grados, que ponen en peligro la vida de las reliquias culturales y requieren mantenimiento y protección urgente. Es esencial realizar una investigación y análisis sistemáticos y detallados de la enfermedad antes de reparar y proteger estos artefactos de piedra.

\section{Sugerencias para citar este artículo}

Wu, Haijia (2020). El status quo y las contramedidas sobre las reliquias de piedra del Templo Putuo Zongcheng en Chengde. Tercio Creciente, 17, págs. 47-70. https://dx.doi.org/10.17561/rtc.n17.4

WU, HAIJIA, El status quo y las contramedidas sobre las reliquias de piedra del Templo Putuo Zongcheng en Chengde. Tercio Creciente, enero 2020. n ${ }^{\circ} 17$, pp. 47-70.

https://dx.doi.org/10.17561/rtc.n17.4

吴海嘉 (2020). 承德普陀宗乘之庙石质文物现状问题及对策. Tercio Creciente, 17, 47-70. https://dx.doi.org/10.17561/rtc.n17.4 
En mayo de 2007, julio de 2012 y agosto de 2016, fui al Templo Putuo Zongcheng en Chengde tres veces para investigar su estado de conservación. Este documento analiza sistemáticamente los tipos existentes de enfermedades y las causas de estas enfermedades al investigar el estado actual de la preservación de los artefactos de piedra en el Templo Putuo Zongcheng. Las razones principales son factores naturales y ambientales, y proponen contramedidas para mejorar el estado de las reliquias culturales de piedra. Las estadísticas de estas enfermedades pueden proporcionar una investigación y una base teórica para la protección y restauración posteriormente.

\section{Abstract:}

The Putuo Zongcheng Temple is the largest temple in the outer eight temples of "Chengde Mountain Resort and Outer Eight Temples". It preserves a large number of stone cultural relics and has a high historical, artistic and scientific value. Under the influence of long-term natural environment and human production activities, these cultural stone relics have experienced climatic diseases to varying degrees, which seriously endanger the life of cultural relics and require maintenance and urgent protection. It is essential to conduct systematic and detailed disease investigation and analysis before repairing and protecting these stone artifacts.

In May 2007, July 2012 and August 2016, I went to the Putuo Zongcheng Temple in Chengde three times to investigate it. This document systematically analyzes the existing types of diseases and the causes of these diseases by investigating the current status of the preservation of stone artifacts in Putuo Zongcheng Temple. The main reasons are natural and environmental factors, and propose countermeasures to improve the status of stone cultural relics. The statistics of these diseases can provide an investigation and theoretical basis for the protection and restoration later.

\section{摘 要:}

普陀宗乘之庙，作为承德 “避暑山庄及外八庙” 外八庙中规模最大的一座庙宇，保存着大 量的石质文物, 具有较高的历史、艺术和科学价值。在长期自然环境和人类生产活动的影 响下，这些石质文物经历着不同程度的风化病害，严重危及着文物的寿命，亟需维修和保 护。在对这些石质文物进行维修和保护之前, 对其进行系统详尽的病害调查分析至关重要

2007年5月、2012年7月和2016年8月，我先后三次到承德，对承德普陀宗乘之庙主要石质 文物及其构件保存现状调研，分析其现存的病害种类，以及产生这些病害的原因。岩石的 风化是最常见的病害, 自然和环境因素是最主要原因。保护环境、预防性保护是改善石质 文物病害现状的有效方法之一。通过这些病害的统计, 可以为以后的保护修复提供实践调 查和理论依据。 


\section{Palabras Clave/Key words / 关键词}

Descripción general, estado de conservación, causas de enfermedades, contramedidas, Templo Putuo Zongcheng / General description, state of conservation, causes of diseases, countermeasures, Putuo Zongcheng Temple / 概况 ; 保存状况 ; 病害成因 ; 对策

\section{Sugerencias para citar este artículo}

Wu, Haijia (2020). El status quo y las contramedidas sobre las reliquias de piedra del Templo Putuo Zongcheng en Chengde. Tercio Creciente, 17, págs. 47-70. https://dx.doi.org/10.17561/rtc.n17.4

WU, HAIJIA, El status quo y las contramedidas sobre las reliquias de piedra del Templo Putuo Zongcheng en Chengde. Tercio Creciente, enero 2020. no 17, pp. 47-70. https://dx.doi.org/10.17561/rtc.n17.4

吴海嘉 (2020). 承德普陀宗乘之庙石质文物现状问题及对策. Tercio Creciente, 17, 47-70.

https://dx.doi.org/10.17561/rtc.n17.4 
ISSN: $2340-9096$

DOI: https://dx.doi.org/10.17561/rtc.n17.4
Enero 2020

Investigación

\section{引 言}

2007年5月、2012年7月和2016年8月，我先后三次到承德 “避暑山庄及外八庙” 外八 庙之一的 “普陀宗乘之庙” 进行调研，主要对其石质文物的保存现状进行调查分析研究。

“避暑山庄及外八庙” 位于中国河北省承德市中心以北，距离北京230公里。它始建 于1703年, 历经清朝三代皇帝: 康熙、雍正、乾隆, 耗时约90年建成, 是清代皇帝夏天避 暑和处理政务的场所 [14]，是中国现存最大的古典皇家园林。

“外八庙” 是清政府为笼络中国的西方和北方的少数民族，依照西藏、新疆喇嘛教寺 庙的形式而建，包括溥仁寺、溥善寺、普宁寺、安远庙、普陀宗乘之庙、殊像寺、须弥福 寿之庙、广缘寺等8座喇嘛教寺庙 [10]。1994年12月, 避暑山庄及外八庙被列入《世界文化 遗产名录》。

\section{一 普陀宗乘之庙概况}

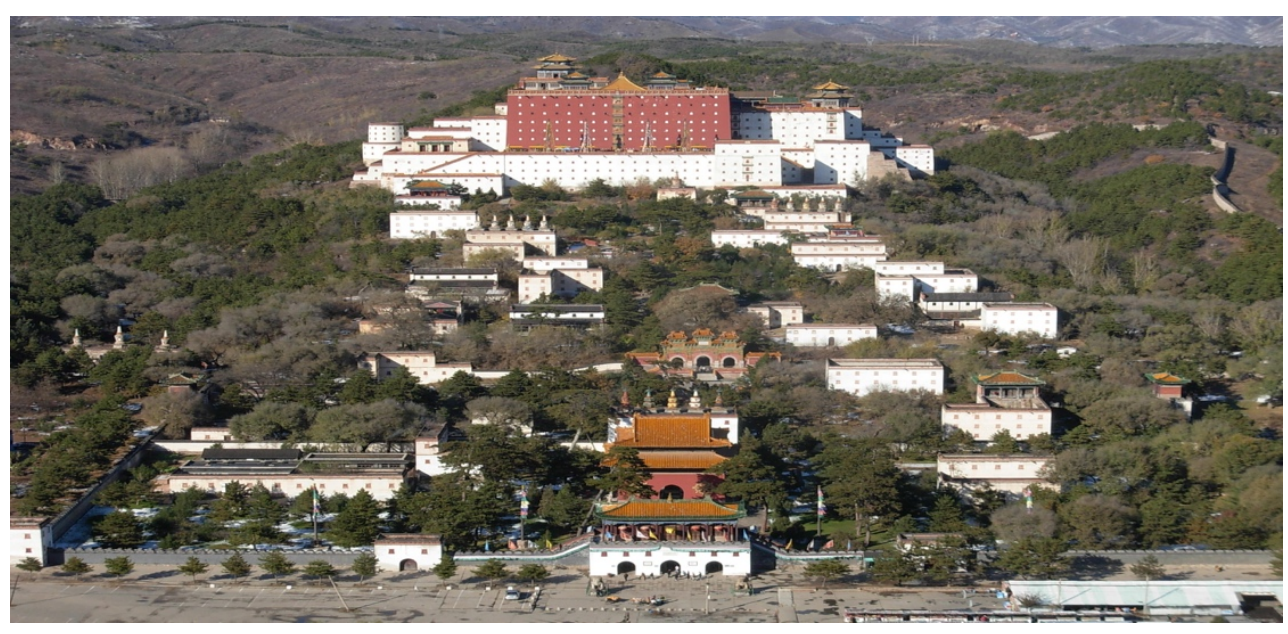

图1 普陀宗乘之庙

作者简介 : 吴海嘉（1968），女，中国四川省叙永县人，成都文物考古研究院， 文博专业技术九级, 硕士研究生, 主要从事文化遗产保护研究。 


\section{（一）普陀宗乘之庙历史沿革}

普陀宗乘之庙位于承德避暑山庄正北，建于清乾隆三十二年（1767年），历经4年完 工，占地面积约 22 万平方米，是外八庙中规模最大的一座庙宇。是乾隆为了庆祝自己六十 寿辰和次年皇太后钮钴录氏八十寿辰两大节日，使前来庆贺的少数民族政教首领看到南疆 大土（观音）的普陀道场，仿照布达拉宫的形式修建的此庙，普陀宗乘是藏语布达拉宫的 汉译，故又称小布达拉宫。

庙的建筑布局利用山势, 自南而北层层升高。主要建筑有山门、碑亭、五塔门、琉璃 牌坊、大红台、万法归一殿等。大红台为主要建筑, 台高43米, 宽59.7米。居于大红台中 部的万法归一殿为重檐四角尖滚金瓦顶。庙内共有大小建筑60处，多是平顶白墙。主体建 筑大红台是一座暗红色的方形建筑，这里是举行重大宗教仪式以及清帝接见重要的少数民 族部落首领及王公大臣们的场所。

\section{庙的整体布局和形制 :}

庙的山门前有五孔石桥一座。山门为砖石砌成，三孔拱门的城台，台上是门殿，山门前 立石狮子一对, 左右两角处建白台隅阁, 周绕围墙, 墙上有难碟。围墙两侧设白台式的腰门 。整个建筑从山下缓坡开始，顺着逐渐升高的地势，自南而北可分为两组不同形式的布局。

前半部分, 即山门以北中轴线上, 有碑亭一座, 亭中有乾隆三十六年御制的三通石碑。 碑亭以北为五塔门。五塔门前是广阔的海墁, 左右立石象一对。塔门左右有一腰墙与后部 隔开, 使前面形成一院落。碑亭两侧相对零散地建有白台数座。从五塔门往北, 顺着石面路 不远就是乾隆时期盛行的 “三间四柱七楼” 式的琉璃牌楼。牌楼往北, 由于地势变化, 在 广阔的斜坡上自由散置一些二三层具有藏族风格的平顶建筑20余座 : 有作为佛殿的木构小 殿; 有作僧舍的小院; 有单塔、五塔, 有不能入内的实心台座。随着迂回的山路, 这些建筑鳞 次栉比, 大红台时隐时现 ${ }^{[13]}$,很自然地过度到寺庙的后方。

后半部即大红台, 大红台是普陀宗乘之庙的主体建筑。从正面看去, 大红台雄伟高大, 全高43米, 分上下两部分。大红台下是巨大的白台基座。在白台的东南方有文殊圣境一座， 西面为千佛阁, 东面为哑叭院 (看管人员回避的地方)。白台基座上为7层高的大红台屹立在 中央, 整个大红台利用天然丘陵, 将三组规模不同的建筑连成一个整体。大红台的中心建 筑万法归一殿, 隐于高处的群楼之间, 左右设蹬道, 东经洛伽胜境, 西经千佛阁后群楼方能登 
达大红台。群楼上方修建的八角和六角亭位于不同的高度, 都使用镭金铜瓦, 金光闪耀, 丰富 了整组建筑的立体轮廓 ${ }^{[13]}$ 。大红台西部有圆形碉堡一座。

\section{（二）普陀宗乘之庙主要建筑}

普陀宗乘之庙主要建筑有山门、碑亭、五塔门、琉璃牌坊、大红台、万法归一殿等。 经现场调查发现, 普陀宗乘之庙目前保存的石质文物, 主要包括碑亭石碑、碑亭台基、碑 亭围栏、石象、石狮、五塔门基座、琉璃牌坊基座、大红台白色基座等。

\section{1、碑亭（图2）}

整个碑亭坐落在白石须弥座上，是一组典型的汉式建筑，平面呈正方形，重檐歇山黄 琉璃瓦顶（用黄色琉璃瓦顶，显示寺庙等级之高。体现了清帝 “兴黄教即所以安众蒙古” 的民族宗教政策）。其四周围以玉石栏杆。碑亭四面开拱门，下有白色台阶，碑亭墙壁呈 红色。亭内立着三通石碑，即《普陀宗乘之庙碑记》、《土尔扈特全部归顺记》、《优恤 土尔扈特部众记》 ${ }^{[8]}$, 用蒙汉满藏四种文字镌刻。碑座为方形, 亚字形座。碑座四面图案 相同, 正一二方一条龙, 龙首突出, 左右下角各一条行龙, 龙身向上。碑身四周浮雕龙戏珠图 案, 左右两侧各刻五条龙, 呈一字排列, 上下两边各是二龙戏珠图案, 碑首亦有 “御制” 字样 [7]。

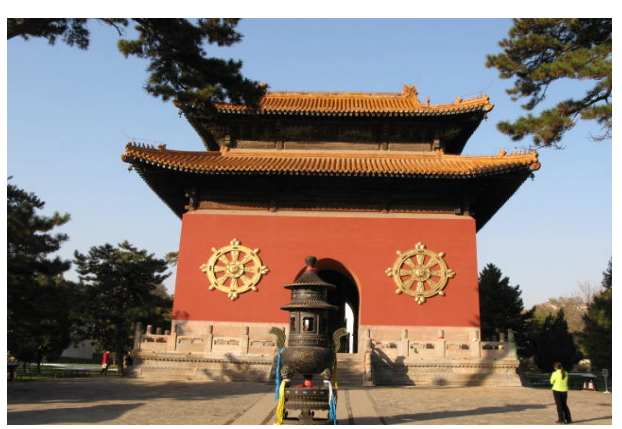

图2 碑亭

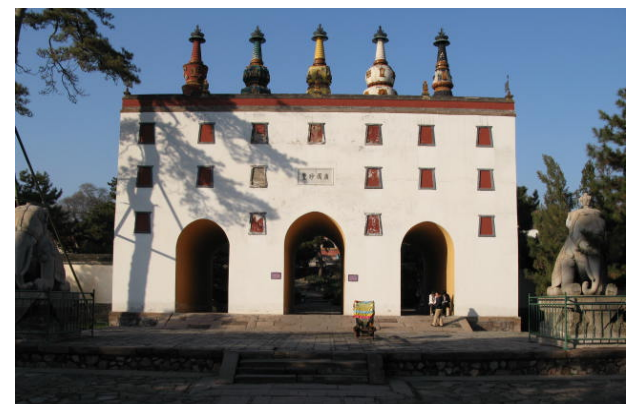

图3 五塔门 


\section{2、五塔门（图3）}

藏式白台五塔门，塔下有三道拱门，台上有红、绿、黄、白、黑五种颜色的喇嘛塔。 其中黄塔象征格鲁派, 红塔象征宁玛派, 白塔象征噶举派, 绿塔象征萨迦派, 黑塔象征笨 波派。五塔门这种建筑形式国内比较少见。五塔门上的喇嘛主要由塔刹、宝珠、宝盖、仰 月、圆光、宝盘、相轮、覆钵和塔座等几部分组成。黄塔置于五塔中央, 表示佛教的一切 教派都以黄教为中心。塔下三道拱门是皇帝和王公大臣的出入通道, 经过时都得仰视佛塔 ，也就是仰视佛祖，敬仰佛法 [8]。

\section{3、琉璃牌坊（图4）}

琉璃牌坊，三间四柱七檐形制，黄绿琉璃瓦覆顶，汉式风格比较突出，故而在藏式寺 庙里格外引人注目。牌坊的中楼前额 “普门应现”，意为这里是观世音普度众生之门。后 匾额为 “莲界庄严” , 意为布达拉是达赖喇嘛居住的圣地, 神圣庄严。匾额上面雕刻着莲 花、忍冬、宝相花、岔角花、缠枝、芭蕉树等纹饰，展示出圣洁、吉祥、忍耐的精神，而 黄绿琉璃瓦及嵌入其中的游龙戏珠图案，又彰显出华丽的皇家气象 [10]。

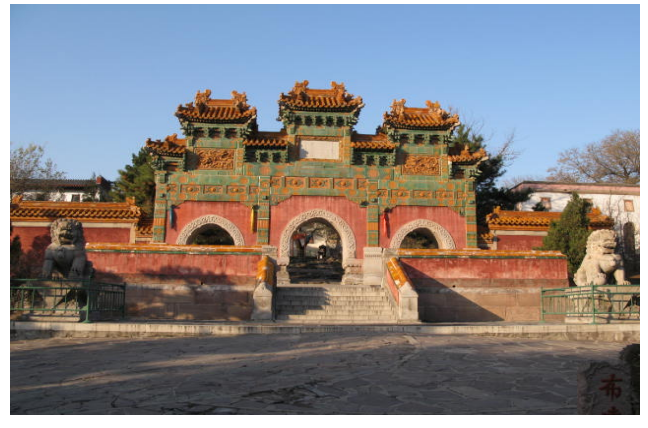

图4 琉璃牌坊

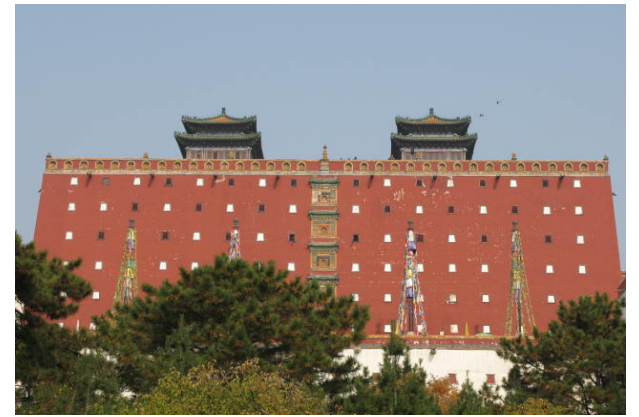

图5 大红台

\section{4、大红台（图5)}

大红台是普陀宗乘之庙的主体建筑，面积约占一万平方米左右，高低错落。全高43米 , 分上下两部分。大红台下面是巨大的白台基座, 高近18米, 下面以花岗岩条石砌筑, 上部 以砖砌筑, 壁面设三层梯形盲窗。

白台基座上为7层高的大红台屹立在中央。高 25 米, 上宽58 米,下宽59.7 米, 形成明显 的收分。红台 1 至 4 层为实心台座, 饰以盲窗, 上面 3 层上下左右间隔开窗。在大红台的南面 
自上而下嵌饰6个琉璃佛芘, 黄绿相间, 突出了大红台的中轴线, 大红台上端的女儿墙以黄琉 璃佛龛3面装橫, 拔檐石下铜制排水长槽伸出壁外近一米, 使大红台的外观坚固有力, 巍峨壮 观。

大红台内部由三组不同类型建筑组合而成。中部由普陀宗乘之庙的主殿万法归一殿及 它周围的群楼组成, 都纲式的布局。万法归一殿方七间, 重檐钻尖顶, 上覆馏金鱼鳞状铜瓦, 屋脊饰以水纹，宝顶呈法铃状，均属西藏寺庙常用的装饰 [10]。东面建洛伽胜境殿和御座楼 , 南在四面群房围绕的戏台（主座亭）与之连接。群楼顶上西北角建重檐六角亭 “慈航普 渡”，群楼东北角建重檐八角亭 “权衡三界” , 都使用镭金铜瓦。

大红台是举行重大宗教仪式的场所，历史上曾接待过六世班禅等重要贵宾。

\section{5、主要石质文物雕像（图6、7、8、9）}

石狮石象居于琉璃牌坊前。狮子是世俗王权的象征，而大象又是佛法无边的象征，狮 象并用，象征政教合一。西藏的达赖喇嘛、班禅额尔德尼是朝廷赐封的活佛，统管着西藏 的政教事务。因此, 狮象配牌坊, 象征朝廷对佛教的高度重视 [8]。

石象（图6、图7）：位于五塔门前, 左右各一个为石质材料所雕砌。

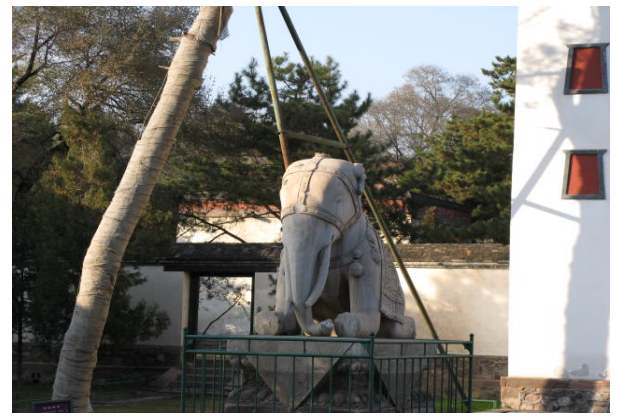

图6 左侧石象

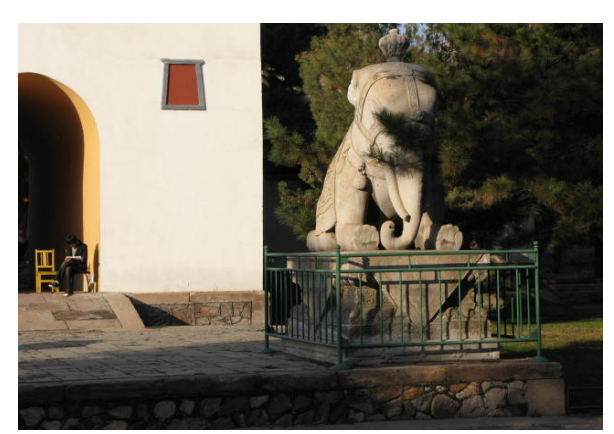

图7 右侧石象 
石狮（图8、图9）：位于琉璃牌坊前, 左右各一个为石质材料所雕砌。

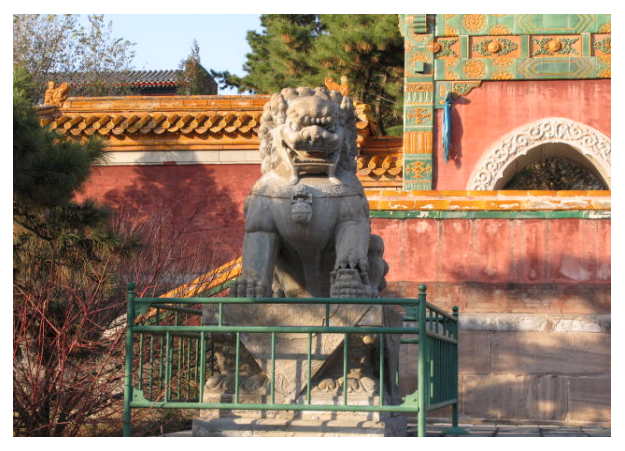

图8 左侧石狮

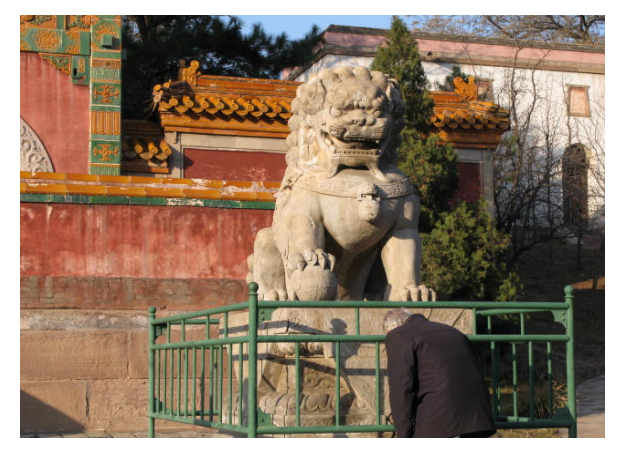

图9 右侧石狮

\section{二 普陀宗乘之庙主要病害类型及其状况分析}

普陀宗乘之庙, 保存着大量的石质文物, 具有较高的历史、艺术、科学和文化社会价 值。在长期自然环境和人类生产活动的影响下，这些石质文物经历着不同程度的风化病害 , 严重危及着文物的寿命, 亟需维修和保护。在对这些石质文物进行维修和保护之前, 对 其进行系统详尽的病害调查分析至关重要。

通过调研, 发现普陀宗乘碑亭、五塔门、琉璃牌坊、大红台以及石象、石狮等主要石 质文物及石质构件保存完整的已屈指可数，大多存在着不同程度的损坏，有些甚至存在较 为严重的开裂、崩损、粉化、生物生长等病害, 两种及两种以上的病害普遍存在于同一种 石质文物上，交叉共存。如石象、石狮局部有的已出现较深的风化剥离层，有的面部、前 后肢和背部等处已残缺不全或开裂缺失; 石材台基出现明显盐析分化脱落等病害, 部分石 材的风化程度随时都有可能产生崩解、剥离。 


\section{(一) 普陀宗乘之庙主要病害类型（表1）}

根据中国国家文物局2008年颁布的《石质文物病害分类与图示》分类标准，普陀宗乘 病害类型归纳如下：

1、表层风化 (如图10、11、12)

石质文物由于外界自然因素的破坏作用而导致的表层病害，多与盐分作用相关。此类病害 普遍存在于露天存放的台基立面石材。碑亭台基、石象、石狮、五塔门基座、琉璃牌坊右 侧门基座以及大红台前石柱均有不多程度的呈现。主要表现为以下几方面：

(1) 表面泛盐: 由于毛细水与可溶盐活动使可溶盐在石材表面富集析出。毛细水活动是 该类病害的主要原因。盐分的来源有地下水中的盐分，水泥修补也会带来盐分。盐分的运 移常导致其表面颜色改变，发生起翘、粉状剥落等劣化现象。

(2) 表面粉化剥落: 由于温湿度周期性变化、冻融作用以及水、盐活动引发石质文物表 面的酥粉剥落的现，较多发生于质地疏松的沉积岩类文物表面，特征是表面出现粉末状物 质，疏松易脱。

(3) 表层片状剥落: 由于外力干扰、水盐活动、温度周期性变化等因素导致的石质文物 表层呈片状、板状剥落的现象。此类病害一般发生于杂质量较多、纹理较为发达的沉积岩 类石质文物表层，且常伴随表层空鼓、起尧等现象。

(4) 表面溶蚀: 露天石质文物由于长期遭受雨水冲刷, 形成表面坑窝状或沟槽状溶蚀现 象。由于受到酸雨的侵蚀, 表面存在不同程度的溶蚀痕迹, 这种现象是由于矿物成分多样 ，被酸雨等选择性腐蚀造成，表面溶蚀病害比较突出，致使表面纹饰普遍模糊不清。

2、不和谐人工干预（如图13、14、15、16）

由于人为采用违背文物修复原则的材料技术以及人为破坏造成文物损伤或改变文物历 史状况。 


\section{3、表面生物病害（如图17、18、19）}

是生物或微生物在石质文物表面生长或繁衍而导致的各类病害。普陀宗乘之庙内石质 文物表面存在不同程度的植物病害、动物病害和微生物病害。现场可发现裂隙中存在蛛网 、杂草、绿色或黑色地衣，长期留存对文物已造成侵蚀。

\section{4、裂隙（如图20、21）}

(1) 浅表性裂隙: 也叫风化裂隙, 主要由自然风化、溶蚀现象引起, 是一种沿石材纹理 发育、比较细小且延伸进内部较浅、多呈里小外大的 $V$ 字形裂隙。但在薄弱夹杂带附 近，这种裂隙会呈条带状分布，且延伸进表层较深。自然风化、溶蚀现象会导致这类裂隙 逐步加深加宽。凝灰岩沉积时的层状特征是产生裂隙的内在因素。

（2）机械裂隙: 也叫应力裂隙，是因受力不均匀、地基沉降、外力干扰、石材自身构造 等而引起的石材开裂现象。通常此类裂隙会深达石材内部，使石刻石碑的整体稳定性受到 威胁，裂隙相互交切、贯穿能导致石质文物局部脱落乃至整体断裂。

\section{5、表面污染与变色（如图22、23、24、25）}

由于灰尘、污染物和风化产物的沉积而导致的石质文物表面污染和变色现象。此类病 害常见的表现形式有 :

（1）大气粉尘污染: 石刻一旦露天存放，其表面通常会有大量灰尘或风化产物覆盖。

（2）水锈结壳: 石质文物露天存放或曾经露天存放，在水的溶蚀和灰尘积聚作用下在 石材表面形成的一层结壳 (多为钙质) [ 15]。

\section{6、机械损伤（如图26）}

由于自然因素和其它外力破坏，普陀宗乘之庙内的石质文物存在较为严重的断裂、缺 失和破碎现象，尤其是台基和石象局部的断裂与缺失。 
Revista de Estudios en Sociedad, Artes y Gestión Cultural

表1 普陀宗乘之庙主要石质文物的病害类型

\begin{tabular}{|c|c|c|c|c|}
\hline 文物 & 病害区域 & 病害种类 & 表现特征 & 图片号 \\
\hline \multirow{5}{*}{ 碑亭 } & \multirow{5}{*}{ 碑亭台基 } & 1、表层风化 & 表面呈刻蚀状残损, 通常伴有下层盐析出 & 10 \\
\hline & & 2、不和谐人工干预 & 水泥修复, 与原材不相容, 人为破坏 & $13 、 14 、 15$ \\
\hline & & 3、表面生物病害 & 地衣苔蘚 & 13 \\
\hline & & 4、裂隙 & 断裂、裂缝并带有表面碎裂 & 20 \\
\hline & & 5、表面污染与变色 & 台基色彩不均 & 24 \\
\hline \multirow{4}{*}{ 石象 } & \multirow{4}{*}{ 五塔门前 } & 1、表层风化 & & 18 \\
\hline & & 2、表面生物病害 & 苔蘚 & 18 \\
\hline & & 3、表面污染变色 & 基座色彩暗淡 & 18 \\
\hline & & 4、机械损伤 & 石象边缘缺失 & 26 \\
\hline \multirow{6}{*}{ 石狮 } & \multirow{6}{*}{ 琉璃牌坊前 } & 1、表层风化 & 盐性粉化剥落 & 11 \\
\hline & & 2、不和谐人工干预 & 水泥沟缝 & 16 \\
\hline & & 3、表面生物病害 & 地衣真菌滋生 & 17、 19 \\
\hline & & 4、裂隙 & 裂缝 & 17、 21 \\
\hline & & 表面污染与变色 & 台基色彩暗淡 & 23 \\
\hline & & 机械损伤 & 断裂脱落残缺 & 21 \\
\hline \multirow{2}{*}{$\begin{array}{c}\text { 琉璃牌 } \\
\text { 坊 }\end{array}$} & 琉璃牌坊 & 表层风化 & 盐性粉化剥落 & 25 \\
\hline & 右侧门基座 & 表面污染与变色 & 色彩不均 & 25 \\
\hline \multirow{4}{*}{ 大红台 } & \multirow{4}{*}{$\begin{array}{c}\text { 大红台前石 } \\
\text { 柱 }\end{array}$} & 表层风化 & 粉化剥落 & 12 \\
\hline & & 不和谐人工干预 & 铁质加固锈蚀 & 22 \\
\hline & & 3、裂隙 & 裂缝 & $12 、 22$ \\
\hline & & 4、表面污染与变色 & 石柱表面锈迹 & 22 \\
\hline
\end{tabular}


Revista de Estudios en Sociedad, Artes y Gestión Cultural

Número 17

Enero 2020

ISSN: 2340-9096

DOI: https://dx.doi.org/10.17561/rtc.n17.4
Investigación

（二）普陀宗乘之庙主要病害种类照片

1、表面风化（图 10、11、12）

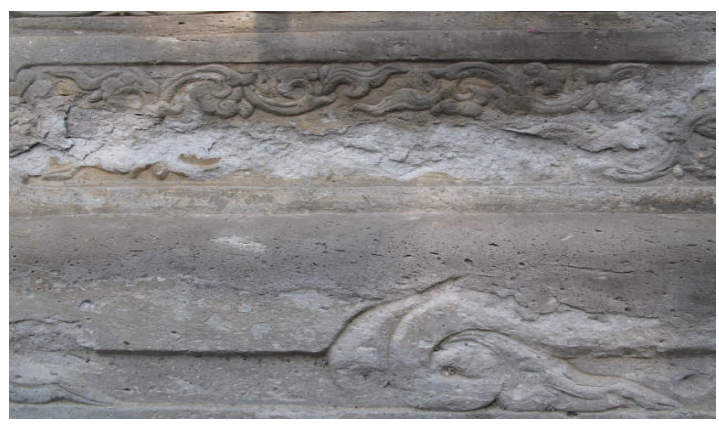

图10碑亭台基 : 盐性腐蚀及剥离

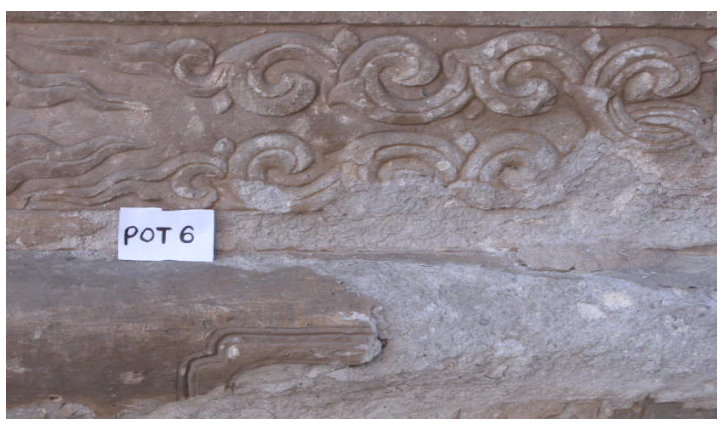

图11石狮底座：盐性粉化剥落

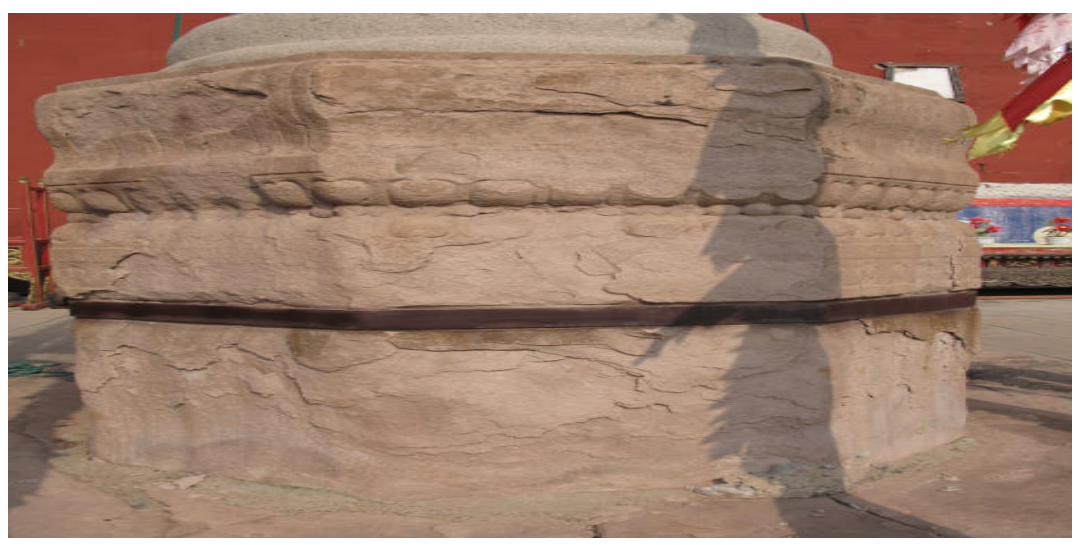

图12大红台前石柱 : 剥落，裂 
Revista de Estudios en Sociedad, Artes y Gestión Cultural
Número 17

Enero 2020

Investigación

DOI: https://dx.doi.org/10.17561/rtc.n17.4

2、不和谐人工干预（图 13、14、15、16）

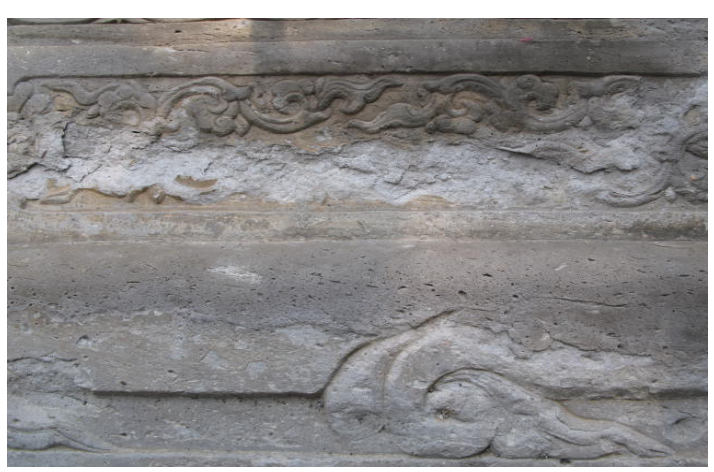

图13碑亭: 不恰当水泥修复, 颜色不均

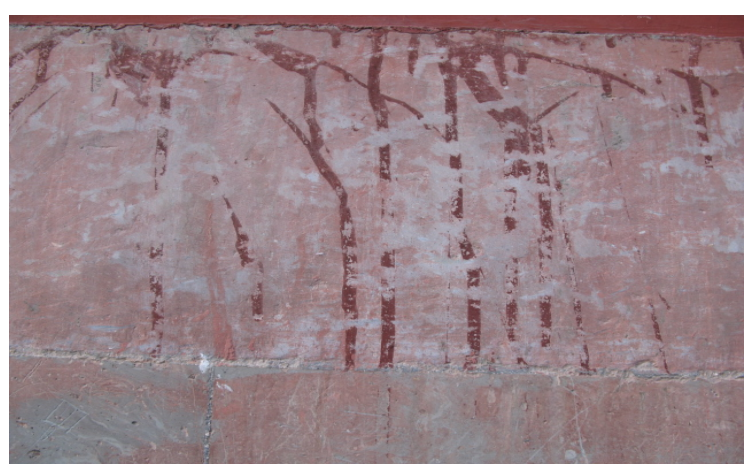

图14碑亭墙: 油漆破坏产生污迹, 变色

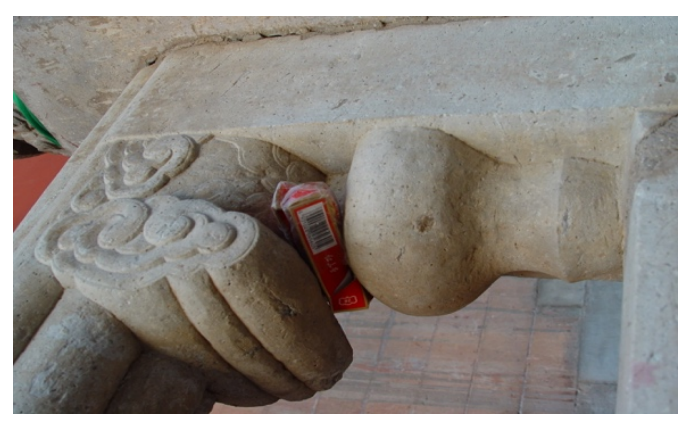

图15 碑亭南面西侧：人为破坏

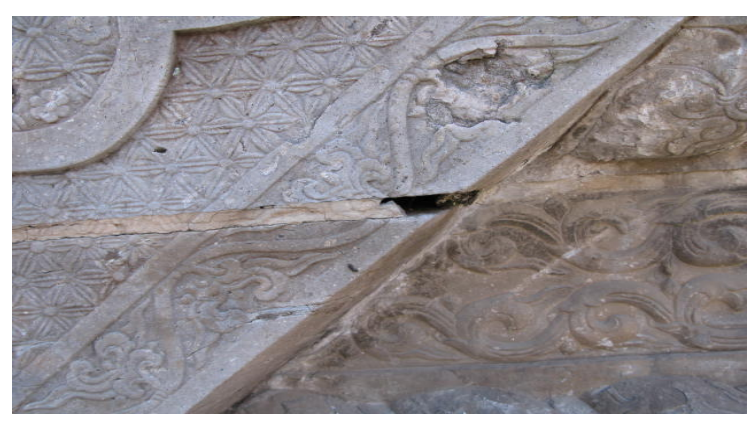

图16石狮底座: 不恰当的水泥沟缝 
Revista de Estudios en Sociedad, Artes y Gestión Cultural
Número 17

Enero 2020

Investigación

DOI: https://dx.doi.org/10.17561/rtc.n17.4

3、表面生物病害（图 17、18、19）

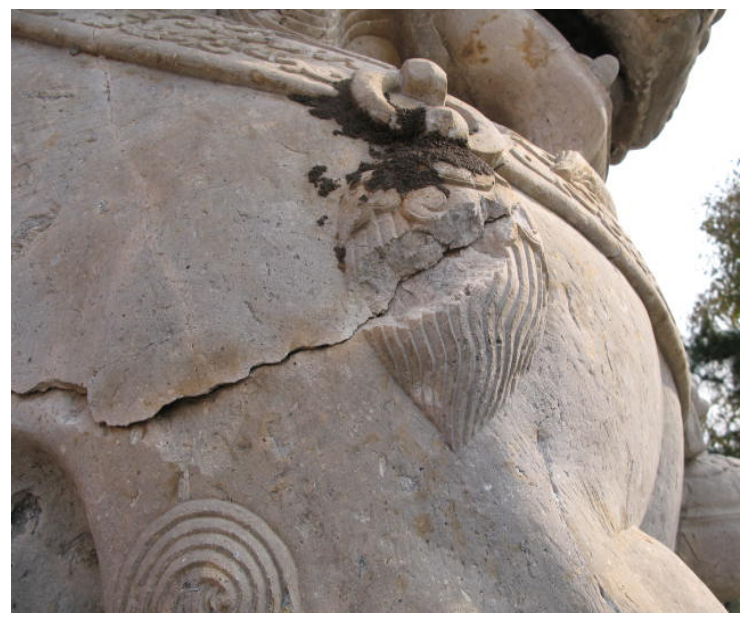

图17石狮头部下面：鸟粪, 缺失裂缝

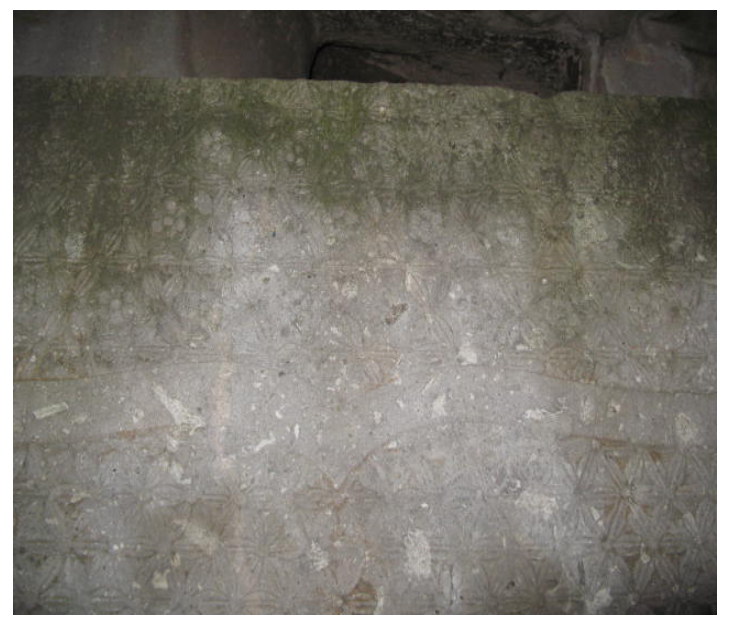

图18石象底座: 微生物, 风化, 变色

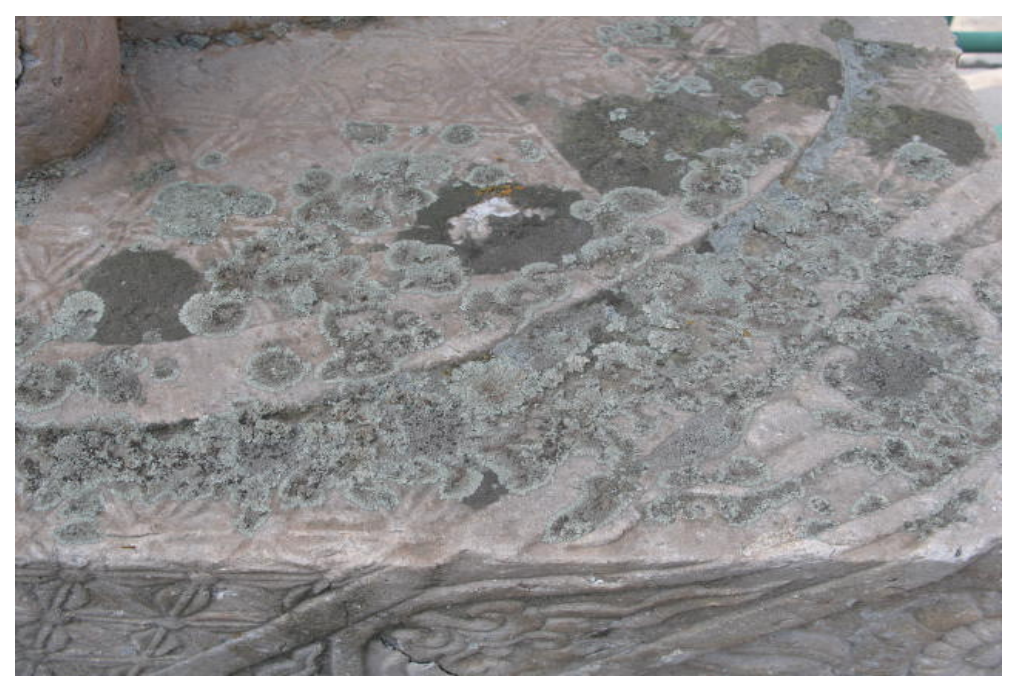

图19 石狮侧背 : 潮湿引起滋生菌和苔藓䨖菌 
Revista de Estudios en Sociedad, Artes y Gestión Cultural
Número 17

Enero 2020

Investigación

\section{4、裂缝（图20、21）}

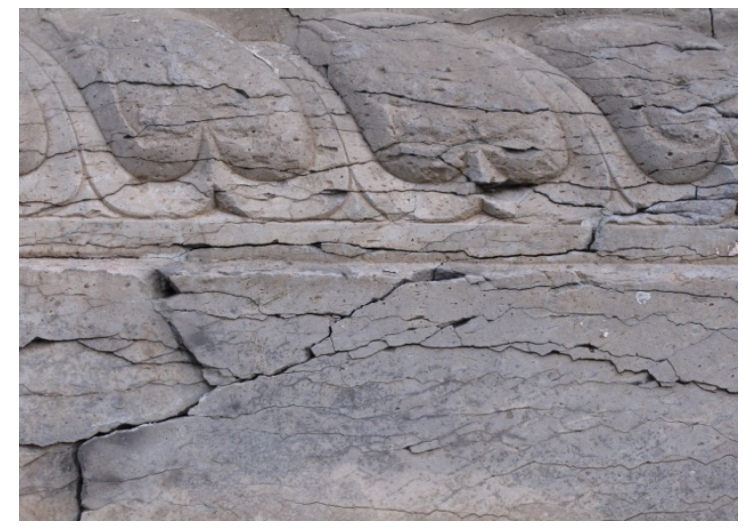

图20 碑亭底座 : 表面线状开裂

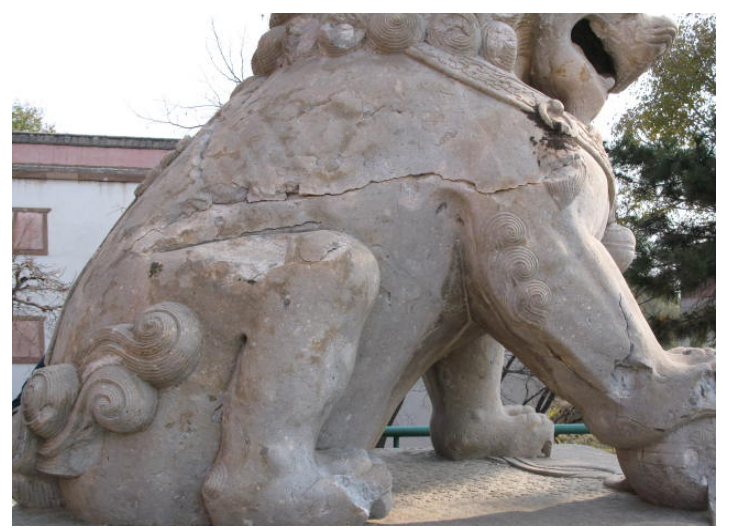

图21石狮侧面: 裂缝, 缺失

5、表面污染与变色（图22、23、24、25）

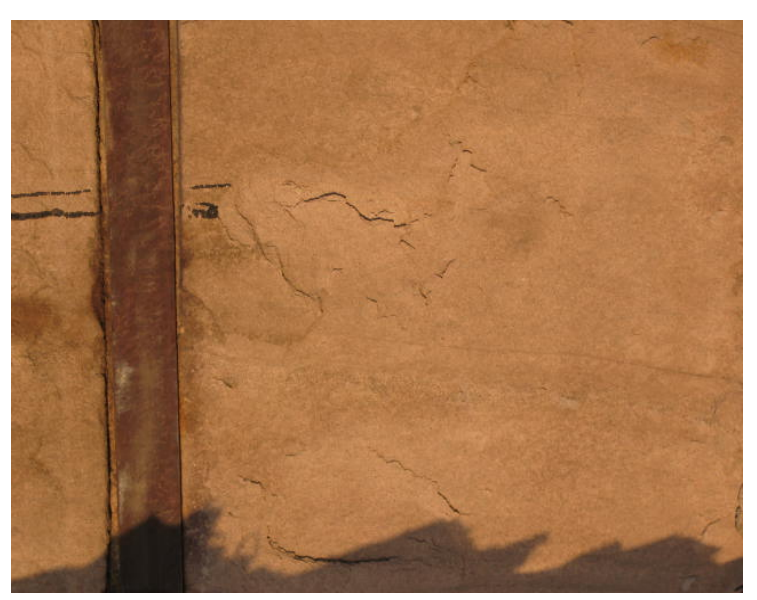

图22大红台前石柱 : 铁质材料加固引起污迹

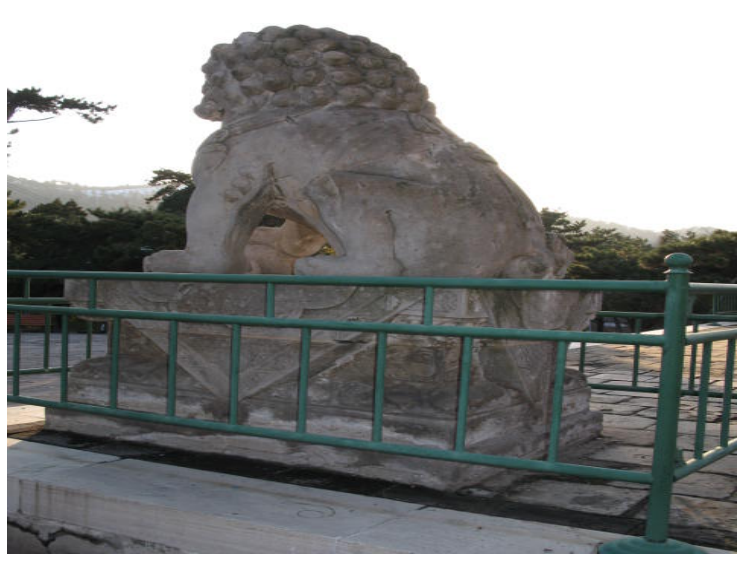

图23石狮底座 : 雨水冲刷引起沉淀 


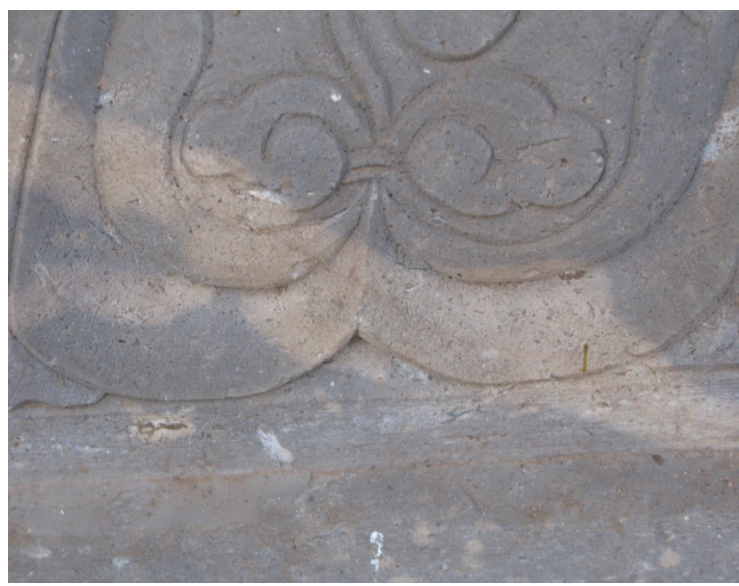

图24 碑亭西底座：石材原因引起色彩不均

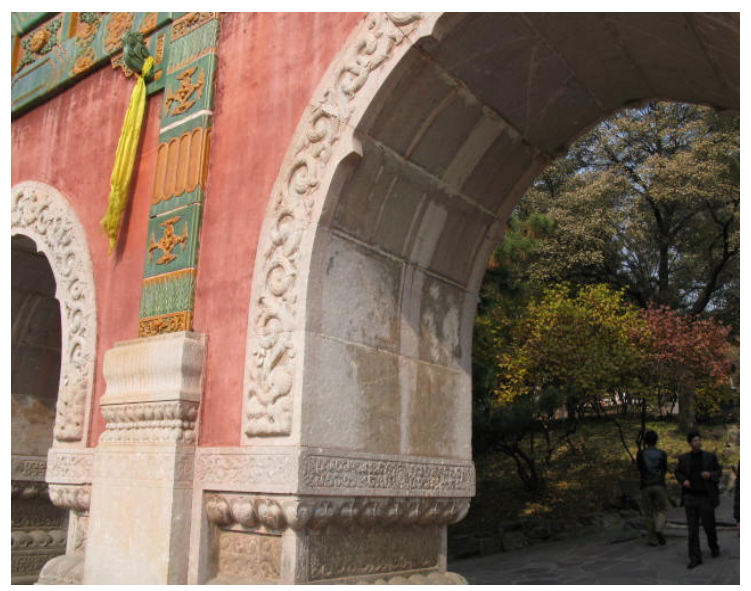

图25 琉璃牌坊右侧门：光照辐射在

不同面引起色彩不均，风化

\section{6、机械损伤（图26）}

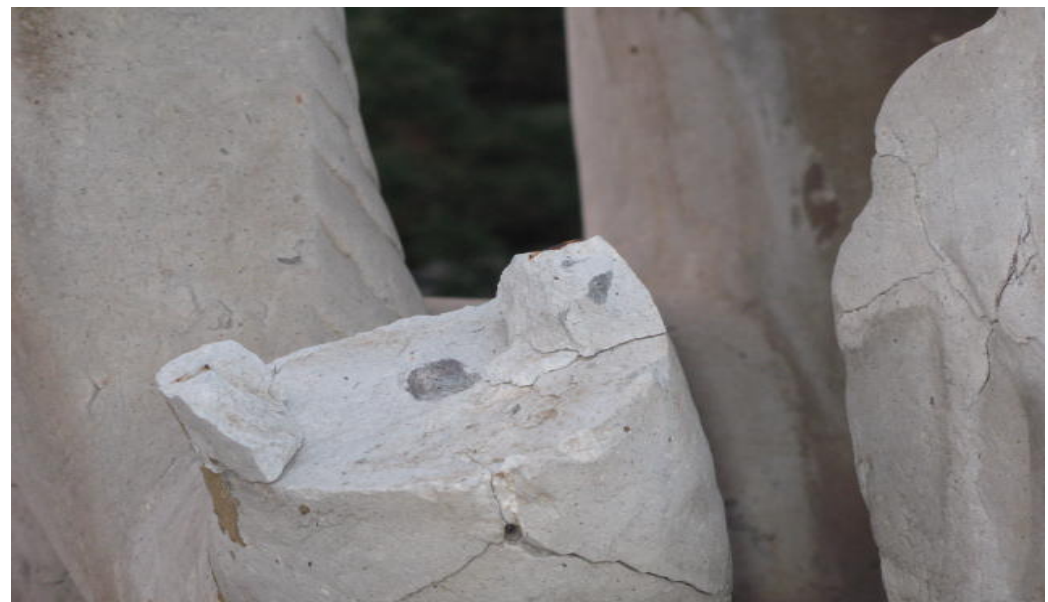

图26石象鼻, 分解粉化引起石头边缘缺失 


\section{三 普陀宗乘之庙石质文物病害成因分析}

普陀宗乘石质文物出现不同程度的病变多与环境密切相关。其中自然因素和人为因素 是两大主要的因素。如自然风化、环境污染、人为因素的干扰，加之无妥善及时的保护修 复, 还有战争、火灾、盗窃等。以及大量游客的涌入也会对文物造成某种程度的人为破坏 ，因为游客释放的热量和二氧化碳，会对石质文物造成了某种程度的干扰和破坏。

\section{（一）自然因素}

\section{1、气候特点}

承德市区地处山谷盆地, 气候类型为寒温带向暖温带过度, 半干旱向半湿润过度, 属 于大陆性、季风型燕山山地气候。具有 “冬冷夏热，四季分明，光照充足，雨热同季，灾 害频繁，昼夜温差大” 的特点。冬季静风频率大，夜晚易形成逆温现象，造成空气不易向 外流通、污染物不易扩散，春季出现扬尘浮尘天气等。

市区与郊区的温度差形成了城市热环流, 进一步加重了承德的环境污染。承德市降 水充足, 平均降水量402 883毫米。过多的降雨, 较为频繁的地下水活动及较大的温差, 冬季的严寒（可达零下 20 多度）与融冻都不利于石质文物的保存。承德市太阳辐射强，年 总量为122154 140876卡/平方厘米，阳光照射角度和强度不同造成色彩变质。

\section{2、种类不同的石材特性}

承德地区矿产资源丰富，岩石种类繁多，主要有红砂岩、青砂岩、火山岩、鹦鹉岩、 花岗岩、砂砾岩等。其中红砂岩和青砂岩, 为沉积岩, 孔隙度为1.6-28.3\%, 吸水率为0.2$7 \%$ 。青砂岩呈豆青角, 红砂岩, 呈暗红色, 质地松脆, 易于加工, 但承重能力较差。使用 范围广，常用于阶条或墁地、金刚墙台基等。

花岗岩, 孔隙度为0.04-2.8\%, 吸水率为0.1-0.7\%。石型坚硬, 石纹粗䊅, 不易于雕刻 , 有粉红、淡黄和灰白等几种颜色, 内有黑点（云母）。产地不同, 石型软硬和石纹的粗 细有差别。因产量多, 硬度高, 建筑上多用制作阶石、柱顶、砌筑台基、驳岸或路面、墙 体，是古建筑用途较多的石材。承德市双桥区大窝铺有一处花岗采石场，相传此地曾专供 避暑山庄及周围寺庙的建筑用材。

鸭鹉岩, 为火山凝灰岩, 为承德特有品种, 具有质地细淢、华美肌理和易于雕刻的特 点。广泛用于室内外建筑的须弥座、塔基、样板望柱和碑刻艺术品, 也作为等级较高的阶 条石、台帮石、卷窗等用材。 
青石，为石灰岩。主要呈灰色或白色，含有机质者多呈黑色。粒细而密，硬度不大， 遇盐酸有气泡反应。种类很多, 但每一种都含有碳酸钙, 常常藏有生物化石。常用于雕饰 构件，如栏杆、佛像底座石狮，也用于台基。

文物建筑本着就地取材、就地加工的原则，大量地使用当地的建筑材料。根据石材不 同的石型用于不同的文物建筑上。普陀宗乘的石质文物建筑主要使用有红砂岩和鹦鹉岩（ 火山凝灰岩）等石材。

由于循环潮湿和冻融变化及因盐分存在，使红砂岩的条石和装饰性石构件上表现出沿 层面的片状剥落。鹦鹉岩对冻融变化的敏感程度不一, 有些残破状况是局部风化、开裂的 结果。而边角缺失也可能是人为的破坏，在有盐分影响的地方，则出现了盐分腐蚀。这些 缺失不仅影响石刻的完美性，有的还在石刻表面形成新的创口，加速石刻风化。而火山凝 灰岩夹杂较多，呈片层状结构，在雨水及毛细水的作用下易造成片层间胶结质流失，过多 水分侵入岩石层理，加上冬季承德地区气候严寒，气温可达零下 20 多度，极易发生融冻破 坏作用。冰䢃的作用下致使石刻表面片状开裂，严重时裂隙相互交切发生大面积龟裂，致 使石刻表面裂隙交叉纵横，丧失其完整性与美观效果，并大大降低石刻强度，极易发生局 部脱落，严重时会对整个题刻的稳定性构成威胁。该类病害也多出现于毛细水活跃部位。

\section{3、水的作用}

水对石材的危害是普遍而严重的，很多病害都是由于水的参与而产生或加剧，尤其是 带有有害物质的水对石材的危害更严重。水通过多种途径侵蚀石材，影响承德地区石材的 水主要有裂隙渗水、地表水和地下水。承德雨季时，大气降水通过裂隙渗入，使石材表面 普遍潮湿, 有的甚至有微细的水流或滴水。地表水沿裂隙下渗, 冲刷裂隙, 并在石材表面 沉积钙质盐类，严重污损石构件。地下水沿各种裂隙下渗过程中，长年累月，不断溶蚀扩 大裂隙，加之地下水毛细渗透，致使石材台基底部风化侵蚀。

特别是水对空隙率大的石材侵蚀, 由于露天存放, 因其石材空隙率较大，在雨水及地 下毛细水的侵蚀下，石材极易发生风化，致使大量可溶盐在石材表面富集，当它们富集到 一定程度时，在雨水及毛细水的侵蚀作用下，通过循环结晶作用，破坏三棱表面结构，不 仅使石刻表面发白泛碱，而且使石刻表面发生酥粉脱落与片状脱落。

\section{（二）环境及其它综合因素}

文物保存的好坏, 既取决于材料质地, 更取决于它所经历的环境, 环境因素影响着文 物的寿命。影响文物损坏的环境因素很复杂, 有温湿度、冻融、盐结晶、风沙、酸雨、植 物、微生物等因素的综合作用，也有空气污染、水、光线辐射等的作用。普陀宗乘之庙石 
质文物及构件病变，与承德的环境状况关系密切，是承德环境因素中多种因素相互关联、 彼此影响的结果。

\section{1、二氧化硫、氮氧化物等酸性有害气体}

承德地区石材病害主要由它本身的材质和它周围的环境所造成的。近年来, 随着经济 的发展，承德周围的自然环境发生了很大的变化，环境污染对石材的威胁日益严重。现承 德周边附近有大小煤矿、铜矿、铁矿多处，矿石开采、运输对环境质量造成很大的影响。

一般来讲，工业污染排放的有害物质对露天石质文物有着直接的损害，尤其是承德地 区大气中的二氧化硫含量普遍偏高，对露天石质文物的影响最甚。承德周边分布着的这些 大大小小的厂矿企业, 造成承德地区大气中二氧化硫含量极高, 而大气中的二氧化硫是形 成酸性雾和酸性雨的主要原因, 空气中的二氧化硫、氮氧化物等酸性有害气体会形成酸雨 、酸雾, 而酸雨是对石质文物危害最为严重的影响因素, 它会产生溶蚀破坏, 这种现象甚 至发生在难溶的花岗岩石质文物上 ${ }^{[26]}$ 。在二氧化硫长期的作用下，还会使坚硬的石灰岩 变成疏松、粉末状的石膏。

大气污染物中影响范围广的主要有含硫化合物、氮氧化合物、碳化合物、颗粒污染物 等, 机动车尾气排放也是大气污染的因素之一。二氧化硫很容易与空气中的水蒸气化合成 为亚硫酸，或者在金属盐类的催化下被氧气作用而形成硫酸。而硫化氢能溶于水形成氢硫 酸, 还能被氧化生成二氧化硫。硫酸把石材中的碳酸钲成分转化成硫酸钙，随着雨水的不 断冲刷, 表面的硫酸钙被冲走，于是又形成新的硫酸钻表层。硫酸钙随环境和温湿度的变 化反复再结晶, 因而容易在石质表面形成硬壳而产生剥蚀脱落 [ 18]。因此, 悬浮在空气中 的尘埃对文物既有物理损伤，也有化学侵蚀，还有生物破坏。

\section{2、工业粉尘的侵蚀}

大量的工业污染排放物, 都不同程度地给承德地区石质文物造成不良影响。由于工 业粉尘黏附性强, 当它飘落在文物表面并粘附在上面, 因其颗粒细微, 不仅对石质表面产 生很强的吸附力, 同时也可吸附大量的有害气体和水汽，造成石质文物病害; 由于粉尘颗 粒的运动可加快真菌孢子的传播, 从而扩大了需菌等有害物质对文物材质的影响范围; 承 德地区的煤、铁、铜的开采运输以及其它加工工厂的生产，化学成分复杂，使工业排放不 同的粉尘，其有害物多样，往往表现共同侵蚀破坏的复杂性。

由于粉尘的吸附而在石材表面产生石膏, 它与岩石中长期水解等作用形成的含结晶水 盐类一起, 当处于低温和高湿环境时吸水膨胀, 对岩石产生压力, 加速了矿物颗粒间连接 的破坏和裂隙的扩张，使岩石表面开裂成页片剥落或碎屃状剥落。在环境干燥时失去或减 少结晶水，体积收缩，在岩石表面形成粉末。 


\section{3、不和谐人工干预}

在早先修复过程中，由于材料有限及认识不够，承德避暑山庄及外八庙的石材文物修 复过程中采用了大量水泥砂浆作为修复材料, 目前这些修补部分已出现了大面积空膨开裂 现象，基本丧失了原有的保护作用，而且使用水泥砂浆作为材料会将大量可溶盐引入石刻 本体，而不利于石刻文物长期保护。

\section{4、风吹雨淋}

石质文物长期露天环境保存，经受风吹雨淋，表面残留有大量灰尘污垢、水锈、生物 污染与风化产物等。风产生的机械力直接作用于石质文物上，携带的地表颗粒击打磨蚀表 面并加深破坏表面的坑窝、裂隙，引起石质文物表层雕刻面漫漶不清。污染物特别是生物 污染物，不仅影响石刻外观，还会对石刻雕像产生不良影响，像生物在石刻表面生长会对 石刻产生根䢃破坏作用，而其在生长过程中新陈代谢产生的大量有机酸碱会对石刻造成腐 蚀破坏作用，这些都不利于石刻的长期保存。风化产物中通常有一定的可溶盐成分，也会 加剧石刻表面风化、表面沉积与生物病害。

\section{四 改善石质文物病害现状的对策}

\section{（一）加强环境整治，减少环境污染，保护文化遗产}

近几十年环境污染对部分石质文物的侵蚀速度超过了过去数百年, 由此可见环境污染 是文物保护的头号杀手，治理环境污染是目前文物保护的首要问题，也是最根本的解决办 法。否则石质文物的风化将进一步加快，精美的石刻艺术将逐渐消亡。

要加强对矿产运输车辆的监管, 保证运输车辆的安全密封性; 对地区的矿产尽量减少 深加工，减少污染源的排放。同时，加快环保技术的实施，提高工业污染物的转化进程。 提高市民素质，共同维护城市环境，保护文化遗产。对于自然环境，虽人为控制较难，但 可以通过监测和预防性措施来缓解环境的负面影响。

（二）加强文物管理，建立石质文物档案制度，实施预防性保护

加强对文物的日常维护, 完善管理措施, 责任到位。建立石质文物环境档案, 为制定 保护修复方案提供科学分析依据。进行日常性维护保养, 定期检查清理石质文物表面灰尘 等沉积物及植物、微生物等, 必要时进行杀虫处理。 
定期监测文物所处环境温湿度的变化、空气污染物的成分、酸雨及灾害性天气，掌握 其对文物的影响程度。采取预防性保护措施, 使用渗透性能强, 透气性能好, 憎水性能佳 , 而酸碱、又可逆的表面防护材料，阻止或减少水的渗透和污染物的化学侵蚀。对损伤、 开裂等提前采取有效防御措施，最大限度消除造成石质文物更大损伤的隐患。在保持文物 历史原真性前提下，对病害严重的部位进行清洗（脱盐、加固、修补、封护等措施 [ 18]。

\section{（三） 根据不同石材特性进行合理修复, 加强维护与保养}

针对不同的石材和产生病害的原因，根据最小干预、可逆性、保全性原则，因地制宜 地制定修复方案和修复使用材料。修复后要环境监测, 收集资料, 以及可能进行的干预： 如清洗干预（除尘，使用喷雾，水洗等）; 进行杀虫、微生物灭活、植物杀死处理等; 对 损伤、断裂情况进行修整。

（四）确立合理的旅游环境容量，实施综合性保护措施

随着中国旅游业的高速发展, 和人们对于传统文化的热爱, 世界文化遗产 “承德避暑 山庄及外八庙” 越来越成为人们参观游览的热点景区之一。自 2004 年以来，到小布达拉宫 参观的非本地人就达到了 40 万以上，平均日流量超过 1000 人。大量游客的涌入，释放的热 量和二氧化碳会对环境造成影响，会对文物造成不同程度的影响和破坏。

通过监测观察, 制定出一套合理的旅游环境容量, 对游客的数量进行控制, 对游客的 行为进行约束和引导。针对人为的破坏因素, 采用综合性保护, 对参观路线不是采取工程 技术来解决，而是从整体系统方面来考虑，诸如采用隔离、限制近观等手段。

\section{（五）开展跨学科研究融合, 有效保护石质文物}

石质文物病害产生是多因素的结果，石质文物保护首先要对石质文物的风化机理进 行研究, 这是多学科的融合, 涉及物理学、化学、环境科学、生物学、地质学、矿物岩石 学等多门学科, 需要将这些学科的技术成就应用到文物保护领域, 逐渐完善文物保护科学 技术 [25], 对石质文物风化机理进行深入、系统、全面的研究, 以便更加科学有效地判定 病害的程度及发展趋势，从而对其实施正确有效的保护措施。

\section{五 结语}

普陀宗乘之庙是清代鼎盛时期留下来的具有历史、文化、民族、艺术、科学和社会价 值的建筑遗存，从不同的侧面反映了当时的社会活动、社会关系、意识形态以及与自然结 合的状况, 具有重要的历史价值, 是人类宝贵的历史文化遗产 [21]。通过调研, 对普陀宗 乘之庙石质文物现状进行了系统的调查与分析。 
由于长期自然环境和人类生产活动的影响，这些石质文物有着不同程度的各种病害， 每一种文物上至少有两种以上的病害类型，既有表面片状剥落、粉状脱落，又有动植物病 害、裂隙、不和谐人工干预等等，这些病害严重危及着文物的寿命。

造成这些病害的原因主要有承德地区特定的自然环境和人为环境以及其它综合因素。 由于石质文物大多露天保存, 受环境的影响更为直接和突出, 这些环境因素不仅改变着石 质文物的外观形态和内部组成，更严重地破坏着石质文物的历史文化特征，即表面的精雕 细刻等细微结构 $[17]$ 。分析研究石质文物的病害现状及其病害成因，统计病害数据，可以 为后期的保护修复工作提供更为详实准确的实践调查和理论依据。

\section{参考文献/Referencias/References}

[1] 承德市文物局.河北省文物局.盖蒂保护研究所.承德殊像寺评估报告[R].2006年.

[1]Chengde Municipal Bureau of Cultural relics. Hebei Provincial Bureau of Cultural relics. Getty Conservation Institute. Evaluation report of Chengde Shuxiang Temple [R]. 2006.

[2] 中国科学院自然科学史研究所主编.中国古代建筑技术史 [M], 北京: 科学出版社, 1985年10月第一版, 2000年1月第三次印刷.

[2] Editor-in-chief of the Institute of the History of Natural Science, Chinese Academy of Sciences. History of Ancient Chinese Architectural Technology [M], Beijing: science Press, the first edition in October 1985, the third printing in January 2000.

[3] 西安文保中心编著.承德石质文物保护方案[R].2007年.

[3] Edited by Xi'an Cultural Security Center. Chengde stone cultural relics protection scheme [R]. 2007.

[4] 陈览君.文物保护与考古科学[J].上海博物馆,2004.

[4] Chen Xiejun. Cultural relic conservation and archaeological science [J]. Shanghai Museum, 2004

[5] 阎学仁.承德外八庙与西藏寺庙建筑[J].西藏研究,1985年,第 1 期.

[5] Yan Xueren. Eight temples outside Chengde and Tibetan temple architecture [J]. Tibetan Studies, 1985, No. 1.

[6] 黄崇文.普陀宗乘之庙的建立及其历史作用[J].西藏研究, 1988年,第 2 期.

[6] Huang Chongwen. The establishment of Putuo Zongsheng Temple and its historical function [J]. Tibet Studies, 1988 , No. 2.

[7] 孙彦荣.外八庙碑亭 [J].承德民族师专学报.1999年,第4期.

[7] Sun Yanrong. The Stele Pavilion of Waiba Temple [J]. Journal of Chengde Teachers College for nationalities.

1999, No. 4.

[8] 李建军.关于普陀宗乘之庙讲解过程中应该注意的几个问题[]].河北旅游职业学院学报,2014年,第1期.

[8] Li Jianjun. Several problems that should be paid attention to in the explanation of Putuo Zongsheng Temple [J]. Journal of Hebei Tourism Vocational College, 2014, No. 1.

[9] 虞绳.承德外八庙建筑二[]].文物参考资料,1956年,第11期.

[9] Yu Sheng. Chengde Outer eight Temple Building II [J]. Cultural relics reference materials, 1956, No. 11.

[10] 绿窗.承德外八庙: 这里不仅是"小布达拉宫"[N]

[10] Green window. Chengde Waiba Temple: this is not only the "Little Potala Palace" [N]

[11] 杨煦.重构布达拉-一承德普陀宗乘之庙的空间布置与象征结构[J].建筑学报,2014年,第9期.

[11] Yang Kui. Reconstruct the spatial layout and symbolic structure of Potala-Chengde Putuo Zongsheng Temple [J]. Journal of Architecture, 2014, No. 9.

[12] 李乾朗.承德普陀宗乘之庙[J].紫禁城,2009年,12期.

[12] Li Qianlang. Chengde Putuo Zongsheng Temple [J]. Forbidden City, 2009, issue 12. 
[13] 杨时英.承德普陀宗乘之庙与西藏布达拉宫[]].西藏研究, 1987,第 4期.

[13] Yang Shiying. Chengde Putuo Zongsheng Temple and Potala Palace in Tibet [J]. Tibetan Studies, 1987, No. 4. [14] 黄槐武.论广西石质文物的保护[J].岭南考古研究,2002年,第2期.

[14] Huang Huaiwu. On the Protection of Stone Cultural relics in Guangxi [J]. Lingnan Archaeological Research, 2002, No. 2 .

[15] 王景勇.承德普佑寺石质文物病害机理研究[J]. 北方文物,2018年,第3期.

[15] WANGJINYOU.Study on the disease mechanism of the stone cultural relics of Chengde Puyou Temple [J] . Northern cultural relics,2018, phase 3

[16] 屈松.张涛等.长城居庸关云台病害现状与原因研究[J], 北京化工大学学报（自然科学版）,2017年,第5期.

[16] qu Song. Zhang Tao, etc. Study on the present situation and causes of Yuntai Diseases in Juyongguan of the Great Wall [J], Journal of Beijing University of Chemical Technology (Natural Science Edition), 2017, No. 5.

[17] 李媭.张瑞芳.周华.圆明园如园石质文物病害调查研究[J].文物鉴定与鉴赏,2018年,第3期.

[17] Li Tong. Zhang Ruifang. Zhou Hua. Investigation and study on the Diseases of Stone Cultural relics in Old Summer Palace Ruyuan [J]. Identification and appreciation of Cultural relics, 2018, No. 3.

[18] 金皓.环境因素对石质文物影响研究[J].文物世界,2015年,第4期.

[18] Jin Hao. Study on the influence of environmental factors on stone cultural relics [J]. World of Cultural relics, 2015, No. 4.

[19] 韩凯英.对馆藏石质文物保护的几点思考 - - 以河南博物院石质文物保护为例 [J].中原文物2013年,第5期.

[19] Han Kaiying. Some thoughts on the protection of stone cultural relics in the collection-- taking the protection of stone cultural relics in Henan Museum as an example [J]. Cultural relics of the Central Plains 2013, No. 5.

[20] 王羽.王明鹏等.露天石质文物生物风化研究进展[J].文博,2015年,第2期.

[20] Wang Yu. Wang Mingpeng et al. Research progress on biological weathering of open-air stone cultural relics [J]. Wenbo, 2015, No. 2.

[21] 李宏松.文物岩石材料劣化特征及评价方法[D].中国地质大学 (北京) 博士学位论文, 2011 .

[21] Li Hongsong. Deterioration characteristics and evaluation methods of cultural relic rock materials [D]. Doctoral thesis of China University of Geosciences (Beijing), 2011.

[22] 张金风. 石质文物病害机理研究[]].文物保护与考古科学,2008年,第2期.

[22] Zhang Jinfeng. Study on the disease mechanism of stone cultural relics [J]. Science of Cultural relic Conservation and Archaeology, 2008, No. 2.

[23] 石质文物病害分类与图示(WW/T 0002-2007) [S].中华人民共和国行业标准, 文物出版社, 2008.

[23] Classification and illustration of diseases in stone cultural relics (WW/T 0002, 2007) [S]. Industry Standard of the people's Republic of China, Cultural relics Press, 2008.

[24] 张建勋.承德普陀宗乘之庙古建筑保护修缮研究 [J].北方文物,2018年,第3期.

[24] Zhang Jianxun. Study on the Protection and renovation of Ancient buildings of Zongsheng Temple in Putuo, Chengde [J]. Northern Cultural relics, 2018, No. 3.

[25] 毛志平.石质文物病害及预防技术分析[]].纵观全局

[25] Mao Zhiping. Analysis of diseases and prevention techniques of stone cultural relics [J]. Look at the overall situation

[26] 马里奥.米凯利、詹长法主编.文物保护与修复的问题卷四[G].北京: 文物出版社, 2009年7月第1版: 310-313页.

[26] Mario. Edited by Micheli and Zhan Changfa. Problems in the Protection and Restoration of Cultural relics Volume IV [G]. Beijing: cultural relics Publishing House, July 2009 1st Edition: 310 Mel 313 pages.

图片来源：除图1来自网络, 其余均出自作者本人现场拍摄。

Source of Pictures: Except for figure 1 from the Internet, the rest are taken by the author herself. Fuente de las imágenes: Excepto la fotografía 1 de Internet, el resto las tomó la propia autora. 